\title{
Correlation between serum lactate levels and outcome in pediatric patients undergoing congenital heart surgery
}

\author{
Doğuştan kalp cerrahisi geçiren pediatrik hastalarda serum laktat düzeyleri ile sonuç ilişkisi

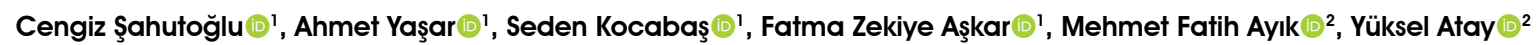 \\ 'Department of Anesthesiology and Reanimation, Medicine Faculty of Ege University, Izmir, Turkey \\ ${ }^{2}$ Department of Cardiovascular Surgery, Medicine Faculty of Ege University, İmir, Turkey
}

\begin{abstract}
Background: This study aimed to investigate the correlation between perioperative arterial lactate levels and morbidity and mortality in children undergoing cardiac surgery.

Methods: A total of 236 patients who underwent open heart surgery due to congenital heart disease (121 males, 115 females; mean age 56.4 month (median: 42 month): range, 1 day to 204 month) between June 2014 and May 2016 were retrospectively analyzed. The arterial blood gas analysis results at baseline (after insertion of arterial cannula), during the cooling and warming-up phases in cardiopulmonary bypass, during the sternal closure, and at $0,6,12$, and 24 hours in the postoperative intensive care unit stay were recorded. The patients were divided into two groups according to their lactate levels: Group 1 (lactate level $<4.5 \mathrm{mmol} / \mathrm{L}, \mathrm{n}=183$ ) and Group 2 (lactate level $\geq 4.5 \mathrm{mmol} / \mathrm{L}, \mathrm{n}=53$ ). Correlation between the lactate groups and demographic data, intraoperative and postoperative variables, postoperative complications, and mortality were investigated.
\end{abstract}

Results: Sixty-nine patients (29.2\%) had cyanotic heart disease. A total of 53 patients $(22.5 \%)$ had lactate levels of $\geq 4.5 \mathrm{mmol} / \mathrm{L}$. At least one complication occurred in $41 \%$ of the patients. Development of at least one complication $(p=0.027)$ and mortality rate $(p<0.001)$ were significantly higher in the patients with lactate levels of $\geq 4.5 \mathrm{mmol} / \mathrm{L}$. Seventeen patients (7.2\%) died in the postoperative period, and 15 of them had lactate levels of $\geq 4.5 \mathrm{mmol} / \mathrm{L}$ at least once within the first 24 hours. In terms of mortality, lactate levels of $\geq 4.5 \mathrm{mmol} / \mathrm{L}$ at any time, prolonged mechanical ventilation ( $>48$ hours), and undergoing complex surgery (high the Risk-adjusted Classification for Congenital Heart Surgery-1 score, category 4-6) were the independent risk factors for mortality.

Conclusion: Blood arterial lactate level of $\geq 4.5 \mathrm{mmol} / \mathrm{L}$ was found to be a risk factor for postoperative morbidity and mortality in pediatric patients undergoing congenital heart surgery.

Keywords: Cardiac surgery; congenital; heart defects; lactate; mortality; postoperative complications.
$\ddot{O} Z$

Amaç: Bu çalışmada doğuştan kalp cerrahisi geçiren pediatrik hastalarda perioperatif arteriyal laktat düzeyleri ile mortalite ve morbidite arasında ilişki olup olmadığı araştırıldı.

Çalışma planı: Haziran 2014-Mayıs 2016 tarihleri arasında doğuştan kalp cerrahisi geçiren 236 hasta (121 erkek, 115 kadın; ort. yaş 56.4 ay (median: 42 ay): dağılım, 1 gün-204 ay) retrospektif olarak değerlendirildi. Başlangıçta (arter kanülü uygulandıktan sonra), kardiyopulmoner baypas soğuma ve ısınma fazında, sternum kapatılması aşamasında ve ameliyat sonrası yoğun bakım kalış süresi $0,6,12$. ve 24 . saatlerdeki arteriyel kan gazı analizleri kaydedildi. Hastalar laktat düzeylerine göre iki gruba ayrıldı: (Grup 1 laktat düzeyi $<4.5 \mathrm{mmol} / \mathrm{L}, \mathrm{n}=183$; Grup 2 laktat düzeyi $\geq 4.5 \mathrm{mmol} / \mathrm{L}, \mathrm{n}=53$ ). Gruplar ile hastaların demografik verileri, ameliyat sırası ve ameliyat sonrası değişkenler, komplikasyonlar ve mortalite arasındaki ilişki araştırıldı.

Bulgular: Altmış dokuz hastada (\%29.2) siyanotik kalp hastalığı vard1. Toplamda 53 hastada (\%22.5) laktat düzeyi $4.5 \mathrm{mmol} / \mathrm{L}$ ve üzerinde idi. Hastaların \%4l'inde en az bir komplikasyon gelişti. Laktat düzeyi $\geq 4.5 \mathrm{mmol} / \mathrm{L}$ grupta en az bir komplikasyon gelişimi $(\mathrm{p}=0.027)$ ve mortalite oranı $(\mathrm{p}<0.001)$ anlamlı olarak daha yüksekti. On yedi hasta (\%7.2) ameliyat sonrası dönemde kaybedildi ve bu hastaların 15'inde laktat düzeyi ilk 24 saatte en az bir kez $\geq 4.5 \mathrm{mmol} / \mathrm{L}$ idi. Herhangi bir dönemde laktat düzeylerinin $\geq 4.5 \mathrm{mmol} / \mathrm{L}$ olması, uzamış mekanik ventilasyon (>48 saat) ve hastanın kompleks cerrahi geçirmesi (yüksek Risk-adjusted Classification for Congenital Heart Surgery-1 skoru, kategori 4-6) mortalite için bağımsız risk faktörü olarak tespit edildi.

Sonuç: Doğuştan kalp cerrahisi uygulanan çocuk hastalarda, arteriyel laktat düzeyinin $4.5 \mathrm{mmol} / \mathrm{L}$ veya üzerinde olmasının ameliyat sonrası morbidite ve mortalite için bağımsız risk faktörü olduğu saptandı.

Anahtar sözcükler: Kardiyak cerrahi; doğuştan; kalp kusurları; laktat; ölüm oranı; ameliyat sonrası komplikasyonlar

Received: December 22, 2017 Accepted: April 23, 2018

Correspondence: Cengiz Şahutoğlu, MD. Ege Üniversitesi Tip Fakültesi, Anesteziyoloji ve Reanimasyon Anabilim Dalı, 35040 Bornova, Izmir, Turkey. Tel: +90 $232-3902143$ e-mail: csahutoglu@yahoo.com 
Lactate is used as a marker for oxygen deficiency in anaerobic metabolism at the tissue level. Increase in tissue lactate concentration is associated with cellular dysfunction due to the depletion of highenergy phosphate compounds. ${ }^{[1]}$ Lactate is produced by erythrocytes, perivenous hepatocytes, skeletal muscle myocytes, and skin and is cleansed by the liver and kidneys. Elevated blood lactate levels indicate increased lactate production, decreased lactate clearance, or both occurring simultaneously. ${ }^{[2]}$ Systemic hypoperfusion, hemodilution, and tissue hypoxia are believed to increase lactate levels in patients undergoing cardiopulmonary bypass (CPB). It has also been shown that cytokine response against $\mathrm{CPB}$ and various metabolic conditions such as $\beta 2$ agonist agents used for hemodynamic stabilization and diabetes increase lactate levels. ${ }^{[1-6]}$ High lactate levels following open heart surgery are often associated with increased postoperative mortality and morbidity rates. ${ }^{[7]}$ High lactate levels have also been shown to correlate with duration of $\mathrm{CPB}$, duration of aortic cross-clamp, inotropic scores, and the Riskadjusted Classification for Congenital Heart Surgery-1 (RACHS-1) subgroups. ${ }^{[8]}$ Lactate elevation is also a risk factor for prolonged intensive care unit (ICU) stay and increased severe postoperative adverse events. ${ }^{[5]}$
However, the methods used in these studies (such as change of lactate level) differ from lactate cut-off values and vary according to surgical procedures. Therefore, the correlation between increased serum lactate levels, complications, and mortality still remains unclear. ${ }^{[8,9]}$

In this study, we aimed to investigate the correlation between lactate levels within the first 24 hours, complications, and mortality in pediatric patients with congenital heart disease undergoing open heart surgery.

\section{PATIENTS AND METHODS}

This retrospective study was approved by the review board of Clinical Research Ethics Committee of Ege University School of Medicine (Decision Number: 16-2.1/7, date: 07/03/2016) and was conducted in accordance with the principles of the Declaration of Helsinki.

A total of 243 patients were included in the study. Seven patients died during the intraoperative period due to heart failure and were excluded from the study to avoid data loss; two patients had truncus arteriosus, two had great arterial transposition, one patients had double outlet right ventricle, one patient had tricuspid

Table 1. Diagnosis of patients

\begin{tabular}{|c|c|c|c|c|}
\hline & \multicolumn{2}{|c|}{ Group 1} & \multicolumn{2}{|c|}{ Group 2} \\
\hline & $\mathrm{n}$ & $\%$ & $\mathrm{n}$ & $\%$ \\
\hline \multicolumn{5}{|l|}{ Non-cyanotic } \\
\hline Atrial septal defect & 47 & 25.7 & 5 & 9.4 \\
\hline Ventricular septal defect & 37 & 20.2 & 5 & 9.4 \\
\hline Atrial septal defect + ventricular septal defect & 12 & 6.6 & 1 & 1.9 \\
\hline Atrioventricular canal defect & 9 & 4.9 & 2 & 3.8 \\
\hline Pulmonary stenosis & 12 & 6.6 & 5 & 11.3 \\
\hline Pulmonary regurgitation & 4 & 2.2 & 4 & 7.5 \\
\hline Systemic valve stenosis & 11 & 6 & 5 & 9.4 \\
\hline Left ventricular outflow obstruction & 5 & 2.7 & 1 & 1.19 \\
\hline Coronary anomalies (ALCAPA) & 2 & 1.1 & 0 & 0 \\
\hline \multicolumn{5}{|l|}{ Cyanotic } \\
\hline Tetralogy of Fallot & 23 & 12.5 & 3 & 5.7 \\
\hline Single ventricle & 4 & 2.2 & 4 & 5.7 \\
\hline Anomalous pulmonary venous return & 4 & 2.2 & 1 & 1.9 \\
\hline Truncus arteriosus & 0 & 0 & 2 & 3.8 \\
\hline Transposition of the great arteries & 4 & 2.2 & 11 & 20.7 \\
\hline Double outlet right ventricle & 7 & 3.8 & 1 & 1.9 \\
\hline Ebstein anomaly & 2 & 1.1 & 1 & 1.9 \\
\hline Hypoplastic left heart & 0 & 0 & 2 & 3.8 \\
\hline Total $(\%)$ & 183 & 100 & 83 & 100 \\
\hline
\end{tabular}

ALCAPA: Anomalous left coronary artery from the pulmonary artery. 
stenosis and hypoplastic right heart, and one patient had tetralogy of Fallot and hypoplastic right heart. Extracorporeal membrane oxygenation (ECMO) was not considered due to the complexity of the pathology and the lack of life expectancy, and no patients died within the first 24-hour postoperative period. A total of 236 pediatric patients (121 males, 115 females; mean age 56.4 months (median: 42 months); range, 1 day to 204 month) who underwent open heart surgery due to congenital heart disease between June 2014 and May 2016 were retrospectively analyzed. The data was obtained from patient records and anesthesia follow-up records. Emergency cases, patients not requiring $\mathrm{CPB}$, preoperatively intubated patients, and those who survived less than 24 hours were excluded from the study.

The primary endpoint was the correlation between elevated lactate levels, complications, and mortality. The secondary endpoint was to determine risk factors for the first 30-day mortality.

The patients' preoperative parameters (age, gender, weight, height, body mass index, RACHS-1 scores, ${ }^{[6]}$ and preoperative diagnosis), intraoperative data (duration of anesthesia, duration of surgery, CPB time, aortic cross-clamp time), and postoperative data (inotropic score at postoperative first hour, use of postoperative blood products within the first 24 hours, duration of mechanical ventilation, intensive care unit (ICU) stay, length of hospital stay, postoperative complications, and 30-day mortality) were recorded. The arterial blood gas analysis results $\left(\mathrm{PH}, \mathrm{PaCO}_{2}, \mathrm{PaO}_{2}\right.$, blood glucose, lactate, hematocrit) and hemodynamic parameters (mean arterial pressure, heart rate, central venous pressure, $\mathrm{SpO}_{2}$ ) were recorded at baseline (after the arterial cannula was administered), during cooling and warming-up phases of $\mathrm{CPB}$, in the course of sternal closure, and at postoperative $0,6,12$, and 24 hours in the ICU stay. The RACHS- 1 consists of six categories (category 1-3 low risk group, category 4-6 high risk group). ${ }^{[10]}$ The vasoactive-inotrope score (VIS) was calculated with the formula: Dopamine dose $(\mathrm{mcg} / \mathrm{kg} / \mathrm{min})+$ Dobutamine dose $(\mathrm{mcg} / \mathrm{kg} / \mathrm{min})$ $+100 \times$ Epinephrine dose $(\mathrm{mcg} / \mathrm{kg} / \mathrm{min})+100 \times$ Norepinephrine dose $(\mathrm{mcg} / \mathrm{kg} / \mathrm{min} 10 \times$ Milrinone dose $(\mathrm{mcg} / \mathrm{kg} / \mathrm{min})$. Inotropic score within the first hour of $\geq 20$ was categorized as high VIS. ${ }^{[11]}$ High lactate level was defined as lactate levels of $\geq 4.5 \mathrm{mmol} / \mathrm{L}$ at least once within the intraoperative period and postoperative first 24 hours. The patients were divided into two groups according to lactate levels measured in arterial blood gas. Group $1(n=183)$ included the patients with a lactate level $<4.5 \mathrm{mmol} / \mathrm{L}$, while Group $2(\mathrm{n}=53)$ included those with a lactate level of $\geq 4.5 \mathrm{mmol} / \mathrm{L}$. The correlation between the demographic data of the patients, their intraoperative and postoperative variables, postoperative complications, and mortality was evaluated in both groups. The following complications were investigated in the study: cardiac complications (right or left heart failure, arrhythmias requiring treatment, ECMO requirement), respiratory complications (pneumonia, re-intubation, acute respiratory distress syndrome, prolonged mechanical ventilation [ $>48$ hours] $)$, renal dysfunction $(0.3 \mathrm{mg} / \mathrm{dL}$

Table 2. Patient characteristics

\begin{tabular}{|c|c|c|c|c|c|c|c|c|c|}
\hline \multirow[b]{2}{*}{$\begin{array}{l}\text { Characteristic } \\
\text { variables }\end{array}$} & \multicolumn{4}{|c|}{ Group $1(n=183)$} & \multicolumn{4}{|c|}{ Group $2(\mathrm{n}=53)$} & \multirow[b]{2}{*}{$p$} \\
\hline & $\mathrm{n}$ & $\%$ & Median & Min-Max & $\mathrm{n}$ & $\%$ & Median & Min-Max & \\
\hline Age (month) & & & 42 & 1 day-204 month & & & 30 & 2 day-180 month & 0.256 \\
\hline Gender & & & & & & & & & 0.160 \\
\hline Male & 89 & & & & 32 & & & & \\
\hline Female & 94 & & & & 21 & & & & \\
\hline $\operatorname{BSA}\left(\mathrm{kg} / \mathrm{m}^{2}\right)$ & & & 0.58 & $0.22-2$ & & & 0.56 & $0.14-1.58$ & 0.337 \\
\hline Cyanotic & 45 & 24.6 & & & 24 & 45.3 & & & 0.006 \\
\hline RACHS-1 & & & & & & & & & $<0.001$ \\
\hline I & 47 & 25.7 & & & 5 & 9.4 & & & \\
\hline II & 83 & 45.4 & & & 21 & 39.6 & & & \\
\hline III & 48 & 26.2 & & & 12 & 22.6 & & & \\
\hline IV & 4 & 2.2 & & & 11 & 20.8 & & & \\
\hline $\mathrm{V}$ & 1 & 0.5 & & & 2 & 3.8 & & & \\
\hline VI & 0 & 0 & & & 2 & 3.8 & & & \\
\hline
\end{tabular}

Min: Minimum; Max: Maximum; BSA: Body surface area; RACHS-1: Risk-adjusted Classification for Congenital Heart Surgery. 


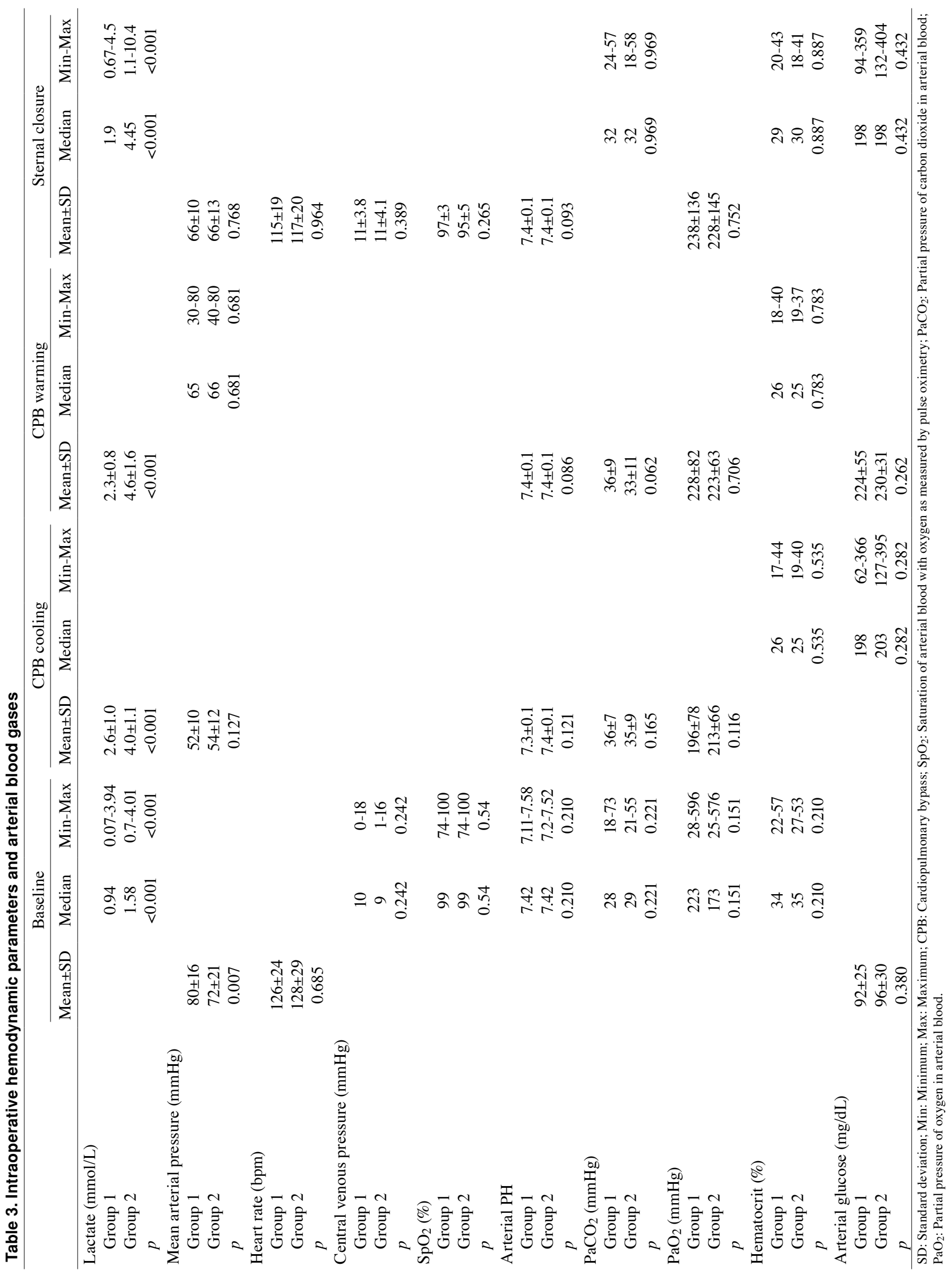




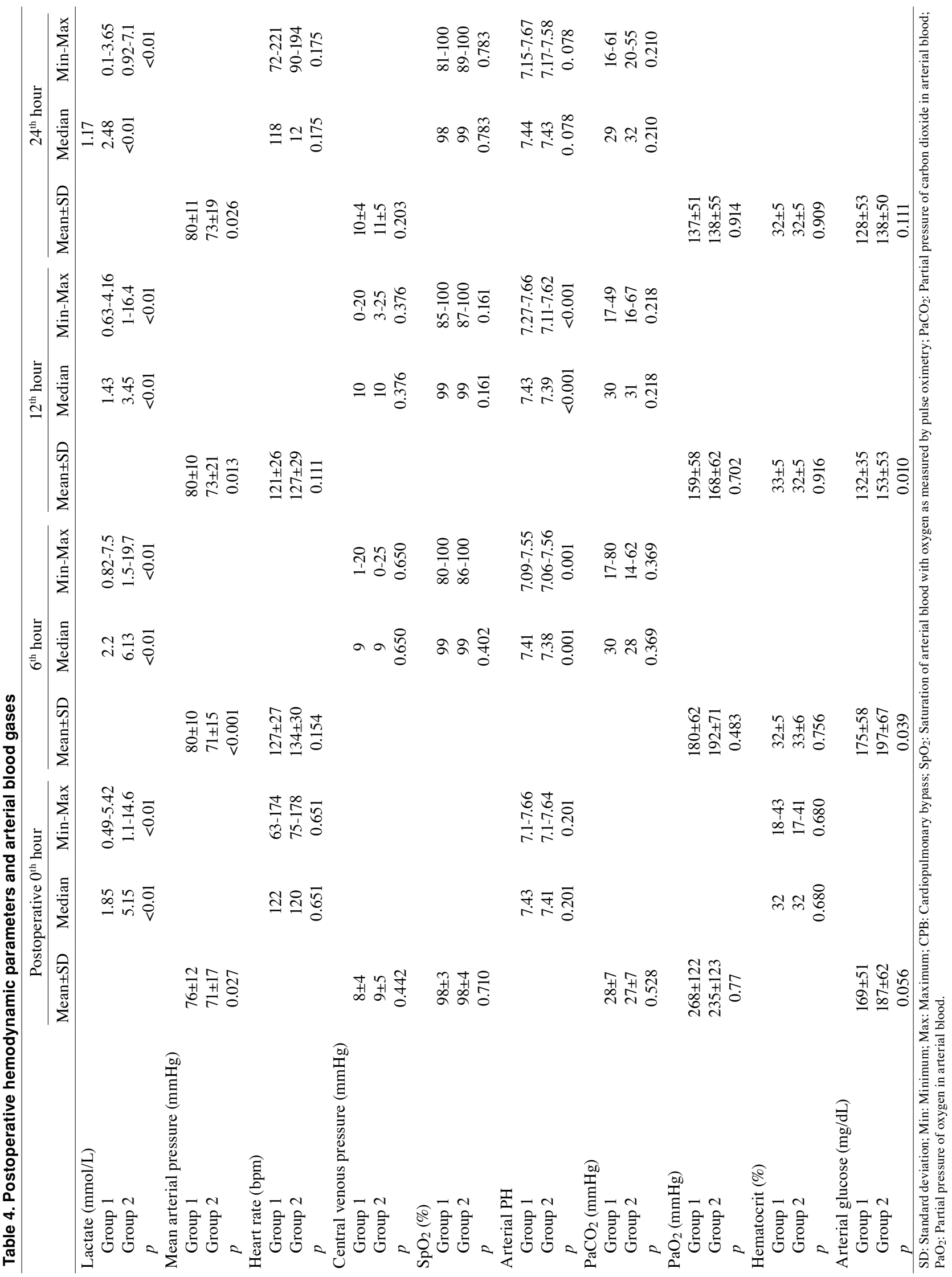


increase in creatinine compared to baseline values, and the need for renal replacement treatment/hemodialysis), cerebrovascular complications (convulsion, cerebral hemorrhage, and cerebral infarct), gastrointestinal complications (ileus, mesenteric ischemia), hematologic complications (massive blood transfusion, hemolysis, and disseminated intravascular coagulation), sepsis, multiple organ dysfunction (MODS), revision, and mortality.

\section{Statistical analysis}

Statistical analysis was performed using the IBM SPSS for Windows version 21.0 (IBM Corp., Armonk, NY, USA). The variables were expressed in mean \pm standard deviation (SD), percentage $(\%)$, and median (min-max) values. The KolmogorovSmirnov test was used to determine whether the variables distributed normally or not. The chi-square and Fisher's exact tests were used for categorical variables, the Independent samples t-test was used to analyze quantitative variables, and the Mann-Whitney U test was used when independent samples t-test was not appropriate. Univariate and multivariate analyses were carried out to examine the mortality-related factors. Significant factors in the univariate analysis were included in the multivariate analysis. Lactate levels of $\geq 4.5 \mathrm{mmol} / \mathrm{L}$ showed the area under the receiver-operating characteristic (ROC) curve to predict 30-day mortality (ROC area: $0.854 ; 95 \%$ confidence interval: 0.761-0.948), with sensitivity, specificity, positive predictive value (PPV), negative predictive value (NPV) and test validity of $88.2 \%, 82.6 \%, 28.3 \%, 98.9 \%$ and $83 \%$, respectively. A $p$ value of $<0.05$ value was considered statistically significant.

\section{RESULTS}

Sixty-nine patients $(29.2 \%)$ had cyanotic heart disease (Table 1 and 2). Four patients (1.7\%) underwent operation under total circulatory arrest, while three patients $(1.3 \%)$ required ECMO (two patients underwent the Norwood procedure and one patient underwent the Jaten procedure). Three patients were discontinued from ECMO, but died due to MODS. The baseline mean arterial pressure (after arterial cannulation) and mean arterial pressure within the first 24 hours postoperatively were lower in Group 2 compared to Group 1, while the intraoperative and postoperative values of heart rate, central venous pressure, blood glucose level (excluding postoperative $6^{\text {th }}$ hour and $12^{\text {th }}$ hour), hematocrit, and arterial blood gas analyses (excluding $\mathrm{PH}$ postoperative sixth hour and $\mathrm{PH}$ postoperative $12^{\text {th }}$ hour) were similar in both groups ( $>0.05$ ) (Table 3 and Table 4). A total of $22.5 \%$ of the patients $(n=53)$ had lactate levels of $\geq 4.5 \mathrm{mmol} / \mathrm{L}$. The intraoperative and postoperative mean lactate levels were higher in Group 2 than Group 1 (Table 3, Table 4, and Figure 1). Eleven percent and $4 \%$ of the patients had lactate levels of $\geq 4.5 \mathrm{mmol} / \mathrm{L}$ at postoperative 12 and 24 hours, respectively. In addition, lactate levels returned to less than $1.5 \mathrm{mmol} / \mathrm{L}$ at the postoperative 24 hours in $58.4 \%$ of the patients (Figure 1). The VIS in $11 \%$ of the patients was more than or equal to 20 , and there was a statistically significant correlation between the increased VIS and increased lactate levels. The VIS was 5 (range: 0 to 40 ) in the group with a lactate level less than $4.5 \mathrm{mmol} / \mathrm{L}$, while the VIS was calculated as $7.5(0-70)$ in the group with a lactate level of $\geq 4.5 \mathrm{mmol} / \mathrm{L}(\mathrm{p}=0.004)$. In all patients, the median red blood cells, fresh-frozen plasma, and platelet use were $147.5 \mathrm{~mL}(0-845), 200 \mathrm{~mL}(0-1005)$, and $20 \mathrm{~mL}$ (0-644), respectively within intra- and postoperative first 24 hours, and there were no statistically significant difference between both groups (Table 5).

A total of 275 complications occurred in $41 \%$ of the patients. The development of at least one complication (Group 1: $37.1 \%$ vs Group 2: $54.7 \%, \mathrm{p}=0.027$ ) and mortality rate (Group 1: $1.1 \%$ vs Group 2: $28.3 \%$, $\mathrm{p}<0.001)$ was significantly higher in the patients with lactate levels of $\geq 4.5 \mathrm{mmol} / \mathrm{L}$. Seventeen patients (7.2\%) died in the postoperative period, while lactate levels in 15 of these patients were $\geq 4.5 \mathrm{mmol} / \mathrm{L}$ within

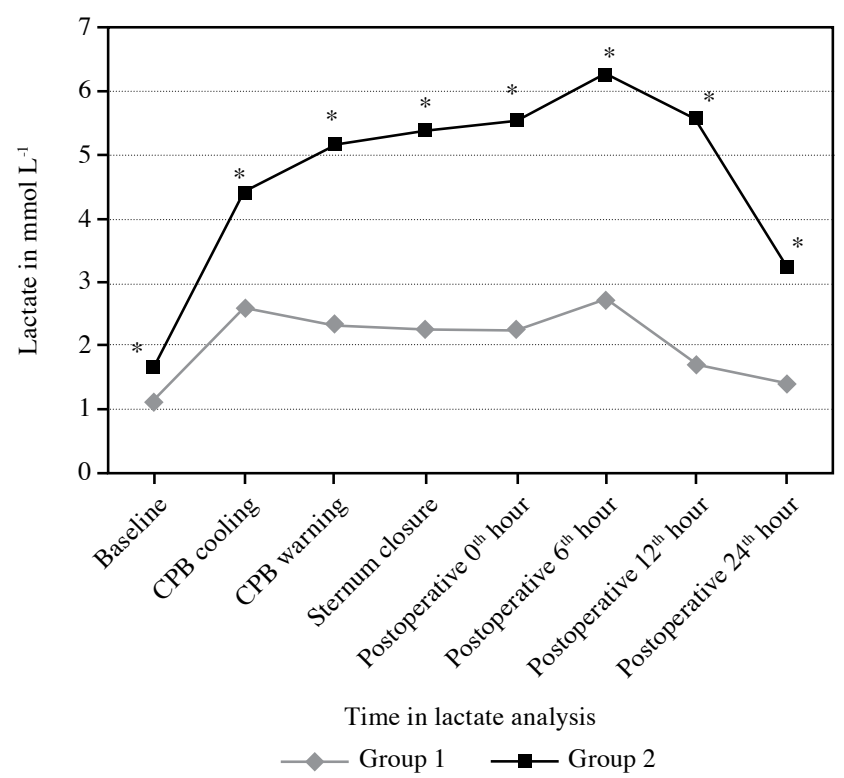

Figure 1. The progress of lactate levels of the group within intraoperative and postoperative first 24 hours.

CPB: Cardiovascular bypass; * $\mathrm{p}<0.001$. 
Table 5. Intraoperative and postoperative variables of the patients

\begin{tabular}{|c|c|c|c|c|c|c|c|}
\hline & \multicolumn{3}{|c|}{ Group $1(\mathrm{n}=183)$} & \multicolumn{3}{|c|}{ Group $2(n=53)$} & \multirow[b]{2}{*}{$\mathrm{p}$} \\
\hline & Mean \pm SD & Median & Min-Max & Mean \pm SD & Median & Min-Max & \\
\hline Duration of surgery (min) & $219 \pm 52.4$ & & & $255 \pm 52.8$ & & & $<0.001$ \\
\hline Duration of anesthesia (min) & $269 \pm 58$ & & & $315 \pm 58$ & & & $<0.001$ \\
\hline CPB time (min) & & 65.5 & $19-198$ & & 90 & $27-162$ & $<0.001$ \\
\hline Aortic cross-clamp time (min) & & 51 & $0-181$ & & 73 & $0-160$ & $<0.001$ \\
\hline Vasoactive-inotropic score & & 5 & $0-40$ & & 7.5 & $0-70$ & 0.004 \\
\hline Duration of MV (hour) & & 4.5 & $1.5-1080$ & & 6.5 & $1.5-792$ & 0.008 \\
\hline Duration of ICU stay (hour) & & 23 & $16-1968$ & & 29 & $12-1680$ & 0.064 \\
\hline Length of stay in hospital (day) & & 7 & $4-91$ & & 8 & $2-92$ & 0.019 \\
\hline Use of ES (mL) & & 135 & $0-715$ & & 175 & $0-845$ & 0.114 \\
\hline Use of FFP (mL) & & 192 & $0-960$ & & 300 & $0-1005$ & 0.053 \\
\hline Use of thrombocyte $(\mathrm{mL})$ & & 20 & $0-340$ & & 30 & $0-644$ & 0.097 \\
\hline
\end{tabular}

SD: Standard deviation; Min: Minimum; Max: Maximum; CPB: Cardiopulmanary bypass; MV: Mechanical ventilation; ICU: Intensive care unit; ES: Erythrocyte suspension; FFP: Fresh frozen plasma.

the first 24 hours (Table 6). Of the 17 patients that died, six patients had transposition of the great arteries, two had single ventricle, two had hypoplastic left heart, two had tetralogy of Fallot, two had atrioventricular canal defect, one had double outlet right ventricle, one had atrial septal defect and ventricular septal defect, and one patient had total anomalous pulmonary venous return. Among them, 13 patients died from MODS, two patients died from cardiac complications, and one patient died from respiratory complications. In terms of mortality, lactate levels of $\geq 4.5 \mathrm{mmol} / \mathrm{L}$ at any time, prolonged mechanical ventilation, and undergoing complex surgery (high RACHS-1 scores) were found to be independent risk factors for mortality (Table 7). The lactate levels ranged from 0.1 to $15.9 \mathrm{mmol} / \mathrm{L}$ in survivors and from 0.7 to $19.9 \mathrm{mmol} / \mathrm{L}$ in nonsurvivors.

\section{DISCUSSION}

In our study, we found that high levels of arterial lactate ( $\geq 4.5 \mathrm{mmol} / \mathrm{L}$ ), complex surgery (high RACHS-1 scores, category 4-6) and prolonged mechanical ventilation duration ( $>48$ hours) were associated with increased mortality in pediatric patients undergoing congenital heart surgery.

Table 6. Distribution of postoperative complications

\begin{tabular}{|c|c|c|c|c|c|}
\hline \multirow[b]{2}{*}{ Types of complications } & \multicolumn{2}{|c|}{ Group 1} & \multicolumn{2}{|c|}{ Group 2} & \multirow[b]{2}{*}{$\mathrm{p}$} \\
\hline & $\mathrm{n}$ & $\%$ & $\mathrm{n}$ & $\%$ & \\
\hline At least one complication & 68 & 37.2 & 29 & 54.7 & 0.027 \\
\hline Respiratory & 29 & 15.8 & 22 & 41.5 & $<0.001$ \\
\hline Cardiac & 43 & 23.5 & 27 & 50.9 & $<0.001$ \\
\hline Neurological & 6 & 3.3 & 11 & 20.8 & $<0.001$ \\
\hline Renal & 11 & 6 & 15 & 28.3 & $<0.001$ \\
\hline Gastrointestinal & 9 & 5 & 6 & 11.3 & 0.110 \\
\hline Hematologic & 12 & 6.6 & 15 & 28.3 & $<0.001$ \\
\hline Multiple organ dysfunction syndrome & 6 & 3.3 & 14 & 26.4 & $<0.001$ \\
\hline Sepsis & 9 & 5 & 7 & 13.2 & 0.057 \\
\hline Revision & 6 & 3.3 & 9 & 17 & 0.001 \\
\hline Mortality & 2 & 1.1 & 15 & 28.3 & $<0.001$ \\
\hline
\end{tabular}


Table 7. Logistic regression analysis of risk factors associated with mortality

\begin{tabular}{lcccc}
\hline & Univariate analysis & & Multivariate analysis & $p$ \\
\cline { 2 - 2 } Age (per month) & OR $(95 \% \mathrm{CI})$ & $p$ & OR (95\% CI $)$ & \\
Weight (increase per kg) & $0.947(0.912-0.984)$ & $\mathbf{0 . 0 0 5}$ & & \\
Cyanotic (yes) & $0.760(0.649-0.890)$ & $\mathbf{0 . 0 0 1}$ & & $\mathbf{0 . 0 4 4}$ \\
High RACHS-1 (yes) & $13.915(3.854-50.238)$ & $<\mathbf{0 . 0 0 1}$ & & \\
Baseline MAP (mmHg) & $15.333(5.022-46.812)$ & $<\mathbf{0 . 0 0 1}$ & $14.73(1.078-201.267)$ & \\
Baseline HR (pbm) & $0.930(0.899-0.963)$ & $<\mathbf{0 . 0 0 1}$ & & \\
SpO 2 (\%) & $1.029(1.007-1.052)$ & $\mathbf{0 . 0 1 0}$ & & \\
VIS $\geq 20$ & $0.916(0.857-0.978)$ & $\mathbf{0 . 0 0 9}$ & & \\
Duration of anesthesia (min) & $18.125(6.083-54.004)$ & $<\mathbf{0 . 0 0 1}$ & & \\
Duration of surgery (min) & $1.014(1.006-1.023)$ & $\mathbf{0 . 0 0 1}$ & & $\mathbf{0 . 0 0 1}$ \\
CPB time (minute) & $1,013(1.004-1.022)$ & $\mathbf{0 . 0 0 3}$ & & 0.077 \\
Cross-clamp time (min) & $1.031(1.017-1.045)$ & $<\mathbf{0 . 0 0 1}$ & $1.025(0.999-1.053)$ & \\
Duration of MV (hour) & $1.024(1.009-1.038)$ & $\mathbf{0 . 0 0 1}$ & & $\mathbf{0 . 0 0 8}$ \\
ICU stay (hour) & $1.007(1.003-1.010)$ & $<\mathbf{0 . 0 0 1}$ & $1.014(1.005-1.022)$ & \\
Lactate $\geq 4.5$ mmol/L & $1.003(1.001-1.004)$ & $\mathbf{0 . 0 0 7}$ & $0.996(0.992-1.0)$ & \\
ES (any quantity) & $35.724(7.842-162.732)$ & $<\mathbf{0 . 0 0 1}$ & $25.252(2.318-275.093)$ & \\
FFP (any quantity) & $1.006(1.001-1.010)$ & $\mathbf{0 . 0 1 0}$ & & \\
\hline
\end{tabular}

OR; Odds ratio; CI: Confidence interval; RACHS-1: Risk-adjusted Classification for Congenital Heart Surgery (category 4-6); MAP: Mean arterial pressure (increase per a value); HR: Heart rate (increase per beat); $\mathrm{SpO}_{2}$; peripheral capillary oxygen saturation (increase per a value); VIS: Vasoactive-inotropic score; CPB: Cardiopulmonary bypass (increase per minute); Cross-clamp time: Aortic cross-clamp time (increase per minute); MV: Mechanical ventilation (increase per hour); ICU: Intensive care unit (increase per hour); ES: Erythrocyte suspension; FFP: Fresh frozen plasma.

Postoperative elevation of lactate levels is expected, and lactate levels of 3-4 $\mathrm{mmol} / \mathrm{L}$ were not considered to be low in previous studies. However, the design of these studies was different, as the cut-off lactate levels were calculated as $3-6 \mathrm{mmol} / \mathrm{L} \cdot \cdot^{[8,12-14]}$ Molina Hazan et al. ${ }^{[8]}$ found that maximum lactate levels (within postoperative first 12 hours) were correlated with the duration of $\mathrm{CPB}$, duration of aortic cross-clamp, the RACHS-1 subgroups, and inotropic scores. Maarslet et al. ${ }^{[12]}$ reported that young age, low weight, high RACHS-1 scores, prolonged duration of $\mathrm{CPB}$, and inotropic use were risk factors for elevated lactate. In addition, a lactate level of $\geq 4.5 \mathrm{mmol} / \mathrm{L}$ led to an increased risk of dialysis (16.9 fold) and mortality (8.4 fold). However, they were unable to find a correlation between increased lactate levels and duration of intubation and ICU stay. Hatherill et al. ${ }^{[13]}$ showed that lactate levels $>6 \mathrm{mmol} / \mathrm{L}$ were weak positive predictive values for mortality on admission to the ICU. Another study reported that increased lactate levels were correlated with the stage of hypothermia in $\mathrm{CPB}$, duration of cardioplegic arrest, duration of mechanical ventilation, and the ICU stay. ${ }^{[14]}$

In our study, a cut-off value of $4.5 \mathrm{mmol} / \mathrm{L}$ was chosen based on previous studies, but the lactate levels were in a wide range. Mortality was seen in only $32.1 \%$ of the patients with lactate levels of $\geq 4.5 \mathrm{mmol} / \mathrm{L}$. This result led to a very weak positive predictive value $(28.3 \%)$. We also found a correlation between the increased lactate levels and high RACHS-1 category, high inotropic scores, being in the cyanotic patient group, long CPB duration, aortic cross-clamp time, duration of operation, and duration of anesthesia.

There are a number of studies that investigate the correlation between lactate and incidence of morbidity and mortality in congenital heart surgery. ${ }^{[14-16]}$ Shemie $^{[14]}$ reported that major complications occurred in 32 of 109 patients, and that lactate levels were higher in patients with complications $(8.6 \pm 6.1 \mathrm{mmol} / \mathrm{Lvs} 3.2 \pm 1.9 \mathrm{mmol} / \mathrm{L})$. Duke et al. ${ }^{[15]}$ reported 12 serious complications in 90 pediatric patients. Blood lactate levels $(>4.5 \mathrm{mmol} / \mathrm{L})$, 
mean arterial pressure (hypotension), and duration of CPB (>150 minute) were independent risk factors for adverse events when measured at the time of admission to the ICU. When lactate levels were $>4.5 \mathrm{mmol} / \mathrm{L}$, the odds ratio was 2.3 (0.5-9.8) for major adverse events. Cardiac output within the first 24 hours, oxygen delivery, mixed venous oxygen saturation, heart rate, and the difference of peripheral-central temperature did not have an effect on major adverse events. Munoz et al. ${ }^{[16]}$ investigated the arterial lactate levels before, during (cooling and warming-up), and after CPB, and upon ICU admission. Serious complications were defined as transfer to the intensive care unit with open sternum, development of renal failure, cardiac arrest, and requirement of resuscitation, requirement for ECMO, and death. High lactate levels were detected in patients who were under total circulatory arrest and in patients who died. A change of over $3 \mathrm{mmol} / \mathrm{L}$ in lactate level during CPB had a sensitivity of $82 \%$ and specificity of $80 \%$. A total of 142 of all patients did not have any complications, while 18 patients developed at least one complication.

In our study, at least one complication developed in 97 patients $(41.1 \%)$. Lactate level of $\geq 4.5 \mathrm{mmol} / \mathrm{L}$ was found to be a significant risk factor for complications. Increased complications developed in the highlactate group which led to an increase in the duration of mechanical ventilation, and length of hospital stay. Because of the fact that some complications (such as pneumonia, increase in creatinine, and renal replacement therapy) may be treated without requiring ICU, no statistically significant difference between increased lactate levels and duration of ICU stay were found.

Mortality after congenital heart surgery is between $8 \%$ and $12.5 \%{ }^{[3-5,8,17-19]}$ Cheifetz et al. ${ }^{[3]}$ reported that six of 48 patients who underwent high risk open-heart surgery died. The patients in the group in which the patients died had significantly higher lactate levels in the postoperative period than that of survivors. All patients with an initial lactate level of less than $7 \mathrm{mmol} / \mathrm{L}$, a maximum lactate level of less than $9 \mathrm{mmol} / \mathrm{L}$ or 4-6 hour period lactate level of less than $4 \mathrm{mmol} / \mathrm{L}$ were discharged from the hospital. In another study, Ghaffari and Malaki ${ }^{[4]}$ found that there was an increase in the arterial lactate levels (1.5-4 mmol/L) for $80 \%$ of 31 patients included in the study, while the arterial lactate levels returned to normal $(<1.5 \mathrm{mmol} / \mathrm{L})$ in $75 \%$ of the patients at postoperative 12 hours. In addition, the persistance of increased lactate levels $(>4 \mathrm{mmol} / \mathrm{L})$ at postoperative 24 hours was associated with poor prognosis.
Schumacher et al. ${ }^{[5]}$ reported a mortality rate of $8.2 \%(n=19)$ in their study involving 231 infants. The increase of $0.6 \mathrm{mmol} / \mathrm{L}$ per hour in lactate levels was a good predictor for mortality (AUC: 0.89, sensitivity: $90 \%$, specificity: $84 \%$, positive predictive value: $34 \%$ and negative predictive value: $99 \%$ ). Similar results were found in subgroups of single or double ventricular heart disease and in different groups of RACHS-1. In a retrospective study involving 255 patients, Molina Hazan et al. ${ }^{[8]}$ investigated the lactate levels at the end of the operation, at ICU admission, and at postoperative 6 and 12 hours. When the Norwood operations were included, the authors reported that the mortality was $10.16 \%(n=27)$. The initial lactate level was $4.22 \pm 3.2 \mathrm{mmol} / \mathrm{L}$ in survivor patients, while it was $8.54 \pm 5.4 \mathrm{mmol} / \mathrm{L}$ in nonsurvivors $(p<0.01)$. In the postoperative period, the serial mean lactate levels were significantly lower in survivor patients than those who died. In addition, the lactate levels in the RACHS-1 subgroups were significantly different between the surviving and nonsurviving patients.

Charpie et al. ${ }^{[17]}$ investigated the lactate levels of 46 patients who underwent complex heart surgery for three days. In the aforementioned study, mortality was seen in five patients and four patients required ECMO. The mean lactate level was $9.4 \pm 3.8 \mathrm{mmol} / \mathrm{L}$ in non-survivors and those requiring ECMO, while it was $5.6 \pm 2.1 \mathrm{mmol} / \mathrm{L}$ in surviving patients $(\mathrm{p}=0.03)$. In addition, the positive predictive value of the initial lactate levels higher than $6 \mathrm{mmol} / \mathrm{L}$ was $38 \%$ for mortality. In contrast, an increase in the lactate levels with $0.75 \mathrm{mmol} / \mathrm{L} / \mathrm{h}$ was associated with poor outcomes $(\mathrm{p}<0.001$, positive predictive value: $100 \%$ ). Ladha et al. ${ }^{[18]}$ found that lactate clearance was higher in survivors than non-survivors. Patients with higher lactate clearance $(>10 \%)$ within the first six hours were found to have improved postoperative outcomes and were found to be associated with decreased mortality rates. In another study, Basaran et al. ${ }^{[19]}$ found that 26 of 60 patients $(43.3 \%$ ) had a mean serum lactate $>4.8 \mathrm{mmol} / \mathrm{L}$. Six patients died in the postoperative period, and all of these patients were in the high lactate group. Mortality was also increased in the group with lactate level $>4.8 \mathrm{mmol} / \mathrm{L}$ $(19.0 \%$ vs $2.9 \%$; $=0.037)$. In multivariate analysis; inotrope score, intubation time, and the ICU stay were found to increase the postoperative lactate levels.

High lactate levels $(\geq 4.5 \mathrm{mmol} / \mathrm{L})$ were found in $22.5 \%(n=53)$ of our patients within any intraoperative and postoperative period (only two patients had a 
baseline lactate level of $\geq 4.5 \mathrm{mmol} / \mathrm{L}$ ). In addition, $28.3 \%$ of the patients in Group $2(n=15)$ died. The lactate levels of the patients reached their peak levels at postoperative $6^{\text {th }}$ hour, and then started to fall off afterwards. Both postoperative high glucose level and low oxygen delivery may contribute to the lactate elevation in the period. Moreover, increased lactate levels may cause increased metabolic acidosis. The mortality in the high-lactate group was $32.1 \%$, while it was $1.1 \%$ in the low-lactate group. Multiple factors were related to mortality in the univariate analysis, whereas multivariate analysis revealed that lactate levels with $\geq 4.5 \mathrm{mmol} / \mathrm{L}$ alone, high RACHS-1 score (category 4-6), and the duration of mechanical ventilation ( $>48$ hour) were significant risk factors for mortality.

\section{Study limitations}

First, this study was retrospectively designed for a wide range of age and disease, which led to a wide range of lactate levels. Second, lactate levels were obtained from routine analyses, and a blind measurement was unable to be performed. Third, since treatment was not independent from the lactate levels of any individual patient, this may have changed the treatment approach of the intensive care specialist.

In conclusion, lactate levels in congenital heart surgery play a critical role in the morbidity and mortality of patients. High Risk-adjusted Classification for Congenital Heart Surgery-1 category, high inotropic scores, being in the cyanotic patient group, prolonged cardiopulmonary bypass duration and aortic cross-clamp time, and prolonged duration of operation and anesthesia may increase lactate levels. In the present study, lactate levels of $\geq 4.5 \mathrm{mmol} / \mathrm{L}$, high Risk-adjusted Classification for Congenital Heart Surgery-1 score (category 4-6), and duration of mechanical ventilation ( $>48$ hours) were found to be independent risk factors for mortality. Although high Risk-adjusted Classification for Congenital Heart Surgery-1 category, and cyanotic condition are unmodifiable risk factors, attention should be paid to the use of inotropic agents and duration of operation should be shortened to reduce the mortality and morbidity rates.

\section{Declaration of conflicting interests}

The authors declared no conflicts of interest with respect to the authorship and/or publication of this article.

\section{Funding}

The authors received no financial support for the research and/or authorship of this article.

\section{REFERENCES}

1. Mizock BA, Falk JL. Lactic acidosis in critical illness. Crit Care Med 1992;20:80-93.

2. Manikis P, Jankowski S, Zhang H, Kahn RJ, Vincent JL. Correlation of serial blood lactate levels to organ failure and mortality after trauma. Am J Emerg Med 1995;13:619-22.

3. Cheifetz IM, Kern FH, Schulman SR, Greeley WJ, Ungerleider RM, Meliones JN. Serum lactates correlate with mortality after operations for complex congenital heart disease. Ann Thorac Surg 1997;64:735-8.

4. Ghaffari S, Malaki M. Arterial lactate level changes in first day after cardiac operation. J Cardiovasc Thorac Res 2013;5:143-5.

5. Schumacher KR, Reichel RA, Vlasic JR, Yu S, Donohue J, Gajarski RJ, et al. Rate of increase in serum lactate level riskstratifies infants after surgery for congenital heart disease. J Thorac Cardiovasc Surg 2014;148:589-95.

6. Minton J, Sidebotham DA. Hyperlactatemia and Cardiac Surgery. J Extra Corpor Technol 2017;49:7-15.

7. Yilmaz S, Yurtseven N, Tuygun AK, Yavuz Y, Canik S. Hyperlactatemia after coronary artery bypass surgery: risk factors and effect on mortality. Turk Gogus Kalp Dama 2011;19:30-5.

8. Molina Hazan V, Gonen Y, Vardi A, Keidan I, Mishali D, Rubinshtein M, et al. Blood lactate levels differ significantly between surviving and nonsurviving patients within the same risk-adjusted Classification for Congenital Heart Surgery (RACHS-1) group after pediatric cardiac surgery. Pediatr Cardiol 2010;31:952-60.

9. Kanazawa T, Egi M, Shimizu K, Toda Y, Iwasaki T, Morimatsu $\mathrm{H}$. Intraoperative change of lactate level is associated with postoperative outcomes in pediatric cardiac surgery patients: retrospective observational study. BMC Anesthesiol 2015;15:29.

10. Jenkins KJ, Gauvreau K, Newburger JW, Spray TL, Moller JH, Iezzoni LI. Consensus-based method for risk adjustment for surgery for congenital heart disease. J Thorac Cardiovasc Surg 2002;123:110-8.

11. Gaies MG, Jeffries HE, Niebler RA, Pasquali SK, Donohue JE, Yu S, et al. Vasoactive-inotropic score is associated with outcome after infant cardiac surgery: an analysis from the Pediatric Cardiac Critical Care Consortium and Virtual PICU System Registries. Pediatr Crit Care Med 2014;15:529-37.

12. Maarslet L, Møller MB, Dall R, Hjortholm K, Ravn H. Lactate levels predict mortality and need for peritoneal dialysis in children undergoing congenital heart surgery. Acta Anaesthesiol Scand 2012;56:459-64.

13. Hatherill M, Sajjanhar T, Tibby SM, Champion MP, Anderson D, Marsh MJ, et al. Serum lactate as a predictor of mortality after paediatric cardiac surgery. Arch Dis Child 1997;77:235-8.

14. Shemie SD. Serum lactate predicts postoperative complications after pediatric cardiac surgery. 307. Pediatr Res 1996;39:54-4.

15. Duke T, Butt W, South M, Karl TR. Early markers of major adverse events in children after cardiac operations. J Thorac Cardiovasc Surg 1997;114:1042-52. 
16. Munoz R, Laussen PC, Palacio G, Zienko L, Piercey G, Wessel DL. Changes in whole blood lactate levels during cardiopulmonary bypass for surgery for congenital cardiac disease: an early indicator of morbidity and mortality. J Thorac Cardiovasc Surg 2000;119:155-62.

17. Charpie JR, Dekeon MK, Goldberg CS, Mosca RS, Bove EL, Kulik TJ. Serial blood lactate measurements predict early outcome after neonatal repair or palliation for complex congenital heart disease. J Thorac Cardiovasc Surg
2000;120:73-80.

18. Ladha S, Kapoor PM, Singh SP, Kiran U, Chowdhury UK. The role of blood lactate clearance as a predictor of mortality in children undergoing surgery for tetralogy of Fallot. Ann Card Anaesth 2016;19:217-24.

19. Basaran M, Sever K, Kafali E, Ugurlucan M, Sayin OA, Tansel T, et al. Serum lactate level has prognostic significance after pediatric cardiac surgery. J Cardiothorac Vasc Anesth 2006;20:43-7. 